\title{
An unusual case of chronic nasal foreign body
}

\author{
Kate Hulse, ${ }_{1}^{1}$ Christopher Thompson, ${ }^{2}$ Rohit Gohil, ${ }_{1}^{1}$ lain Hathorn ${ }^{1}$
}

'Department of Otolaryngology, NHS Lothian, Livingston, UK ${ }^{2}$ Anatomy, Division of Health Sciences, University of Edinburgh, Edinburgh, UK

\section{Correspondence to}

Christopher Thompson, christhompson3@nhs.net

Accepted 1 May 2018

\section{DESCRIPTION}

A 15 -year-old boy was referred to the ear, nose and throat department with a 5 -year history of leftsided nasal obstruction and purulent, foul-smelling nasal discharge. On flexible nasendscopy, mucopurulent discharge from the left middle meatus was noted and the nasendoscope could not be passed beyond this point. The right nasal passage was entirely normal.

A CT scan of the sinuses demonstrated a hyperdense, irregular mass measuring $2.5 \times 2.5 \mathrm{~cm}$ in the left posterior nasal airway, projecting into the nasopharynx (figure 1). There was no history of foreign body insertion.

Operative findings during examination under anaesthetic were of a large occlusive foreign body lodged in the posterior nasal cavity between the septum and inferior turbinate, eroding into the nasal septum (figure 2). There was distortion of the floor of the nasal cavity noted, where the foreign body had caused anatomical remodelling. Due to the size of the foreign body, it had to be pushed posteriorly into the oropharynx and retrieved via the oral cavity.

On examination of the object, it was encrusted in dark, friable, carbonaceous material with a solid central core of an unidentifiable nature (figure 3). Pathological analysis of the specimen demonstrated dark clot with discrete fragments of copper-coloured metallic foil within, consistent with a foreign body. Unsurprisingly the patient's symptoms were relieved following its removal.

This is an unusual case of a large chronic nasal foreign body with no known history of insertion. If the patient had indeed had symptoms for the previous five years, this suggests the foreign body was inserted

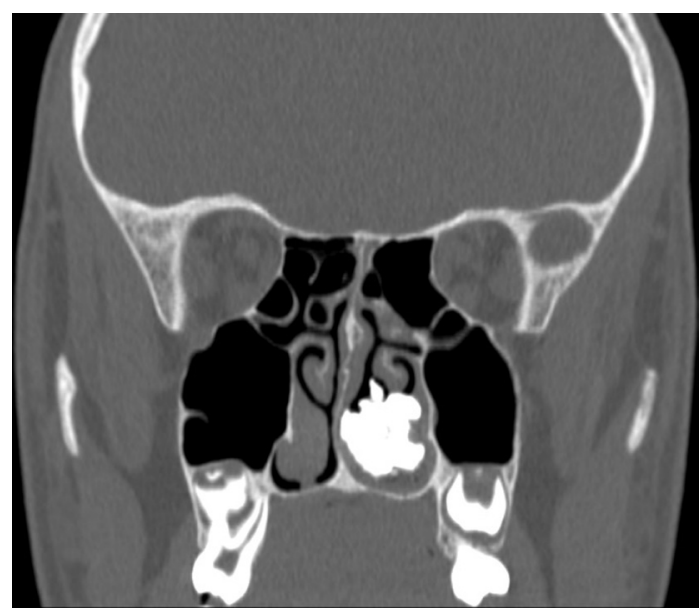

Figure 1 A coronal $\mathrm{CT}$ of the foreign body in the left nasal cavity.

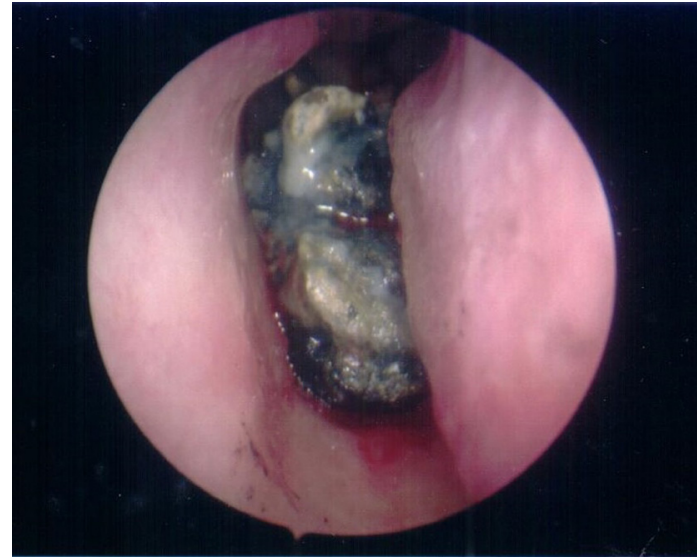

Figure 2 Endoscopic image of the foreign body in the left nasal cavity.

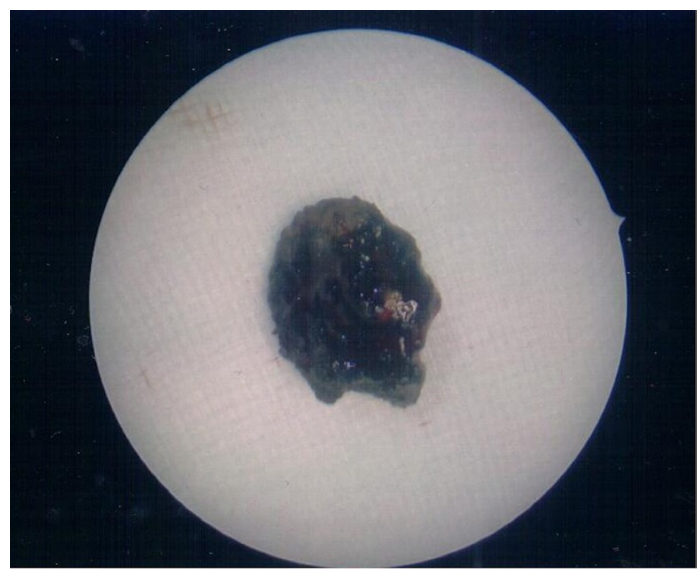

Figure 3 The nasal foreign body post removal.

Learning points

- A nasal foreign body should be considered as a cause for unilateral nasal obstruction and discharge.

- Nasal foreign bodies may not have a clear insertion history, even in adolescents/adults.

- Rhinoliths are calcified nasal masses which present with chronic nasal obstruction, discharge, foul odour and facial pain.

when he was around age 10, which would be unusual in a child without learning disability.

What is even more curious is how the object became lodged in the posterior nasal space when it was clearly too large to fit through the nasal passage. One possibility is that the object was actually ingested and inserted in a retrograde fashion after forceful coughing or vomiting. ${ }^{1}$ 
Another possibility is that a much smaller foreign body was inserted anteriorly and then acted as a nucleus for rhinolith formation. Rhinoliths arise when chronic inflammation of the nasal mucosa and stagnation of mucus, often caused by a neglected foreign body, leads to deposition of calcium and other mineral salts onto its surface. ${ }^{2}$ This concretion of salts leads to progressive growth of the object, which appears as a hyperdense structure on CT scan. By this mechanism, it is conceivable that the foreign body was inserted when the patient was much younger and took many years to become symptomatic due to its slow growth.

Contributors Conception and design: all authors. Consent: KH. Acquisition of data: $\mathrm{KH}, \mathrm{RG}$ and IH. Writing of report: $\mathrm{KH}$ and CT. Proofreading: all authors.
Funding The authors have not declared a specific grant for this research from any funding agency in the public, commercial or not-for-profit sectors.

Competing interests None declared.

Patient consent Guardian consent obtained.

Provenance and peer review Not commissioned; externally peer reviewed.

(C) BMJ Publishing Group Ltd (unless otherwise stated in the text of the article)

2018. All rights reserved. No commercial use is permitted unless otherwise expressly granted.

\section{REFERENCES}

1 MacNeil SD, Moxham JP, Kozak FK. Paediatric aerodigestive foreign bodies: remember the nasopharynx. J Laryngol Otol 2010;124:1132-5.

2 Kose OD, Kose TE, Erdem MA, Kose, MA Erdem TE, Cankaya AB, et al. Large rhinolith causing nasal obstruction. BMJ Case Rep 2015;2015.

Copyright 2018 BMJ Publishing Group. All rights reserved. For permission to reuse any of this content visit

http://group.bmj.com/group/rights-licensing/permissions.

BMJ Case Report Fellows may re-use this article for personal use and teaching without any further permission.

Become a Fellow of BMJ Case Reports today and you can:

- Submit as many cases as you like

- Enjoy fast sympathetic peer review and rapid publication of accepted articles

- Access all the published articles

Re-use any of the published material for personal use and teaching without further permission

For information on Institutional Fellowships contact consortiasales@bmjgroup.com

Visit casereports.bmj.com for more articles like this and to become a Fellow 